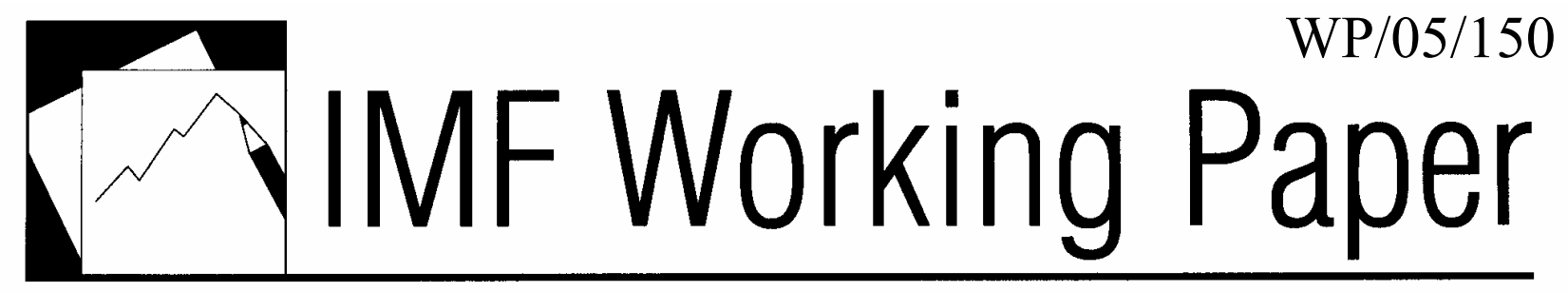

\title{
Infrastructure Aid, Deindustrialization, and Welfare
}

\author{
E. Kwan Choi
}




\title{
IMF Working Paper
}

Fiscal Affairs Department

\author{
Infrastructure Aid, Deindustrialization, and Welfare \\ Prepared by E. Kwan Choi $^{1}$ \\ Authorized for distribution by Sanjeev Gupta
}

July 2005

\begin{abstract}

\section{This Working Paper should not be reported as representing the views of the IMF.} The views expressed in this Working Paper are those of the author(s) and do not necessarily represent those of the IMF or IMF policy. Working Papers describe research in progress by the author(s) and are published to elicit comments and to further debate.
\end{abstract}

This paper investigates the deindustrialization and welfare effects of infrastructure aid in developing countries. In the short run, cost-saving infrastructure aid in the export sector increases the domestic wage rate, whereas the same aid in the import sector lowers it. The cost of nontraded goods rises whether the export or the import sector receives infrastructure aid. Infrastructure aid in the nontraded sector has no effect on domestic factor prices. Laborsaving infrastructure aid causes an expansion of the export sector, while capital-saving infrastructure aid results in a Dutch disease effect in the export sector. If aid is below the optimal level, infrastructure aid increases consumer income and welfare.

JEL Classification Numbers: F1, F35

Keywords: Infrastructure Aid, Deindustrialization

Author(s) E-Mail Address: kchoi@iastate.edu

\footnotetext{
${ }^{1}$ This paper was written while I was a visiting scholar at the International Monetary Fund during the summer of 2004. I am indebted to Sanjeev Gupta, Benedict Clements, Shamshudin Tareq, and Tahsin Saadi Sedik for their helpful comments and assistance. My thanks also go to a few anonymous reviewers.
} 


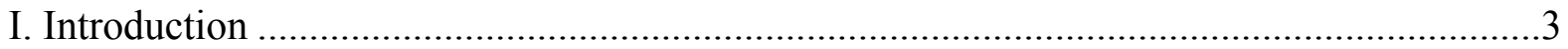

II. The Basic Model …......................................................................................

Short-Term Effects of Infrastructure Investment on Production Costs ............ 7

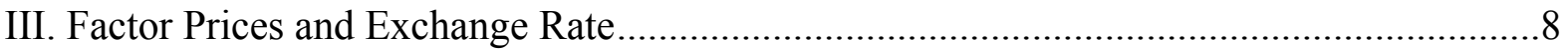

Infrastructure Aid and Externality ........................................................11

IV. When Aid Causes Dutch Disease .........................................................................13

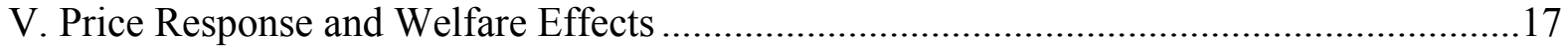

Import Demand and Consumer Income ................................................... 18

Welfare Effect............................................................................. 19

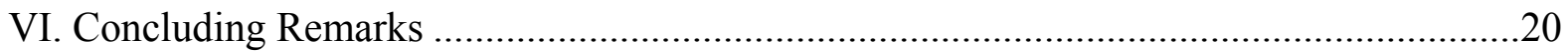

Figures

1. Infrastructure Investment and Dutch Disease .............................................................6

2. Infrastructure Investment with Negative Externality .............................................. 12

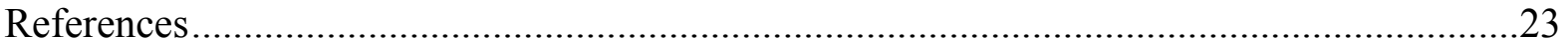




\section{INTRODUCTION}

Despite steady growth in income in developing countries, official development assistance (ODA) steadily declined in the 1990s. Moreover, critics argue that aid may have undermined the growth of the few low-income countries that received aid, through a "Dutch disease" effect, namely currency appreciation and a subsequent decline of the export sector. ${ }^{2}$ Policy makers, who often support increased aid to developing countries, have voiced their concern as a result of such studies. Possible deindustrialization and an adverse impact on the welfare of recipient countries seem to justify reluctance or caution on the part of donor countries.

There is now a substantial body of literature investigating the impact of aid in developing countries, with differing conclusions. Based on his analysis of 62 developing countries, Elbadawi (1999) reported currency overvaluation in aid recipients, and a failure of lowincome countries in sub-Saharan Africa to attract private capital flows. Younger (1992) noted that an increase in aid resulted in currency appreciation and Dutch disease in Ghana. Adam and Bevan (2003) also reported the presence of the Dutch disease effect as a result of aid in their simulation study of Uganda. Using a computable general equilibrium (CGE) model, Vos (1998) stated that aid produced a strong Dutch disease effect in Pakistan. On the other hand, Nyoni (1998) reported that aid inflows, together with increased openness, resulted in currency depreciation, refuting the proposition that foreign aid caused the Dutch disease in Tanzania. Similarly, Bandara (1995) showed that despite currency appreciation, foreign capital inflows to Sri Lanka caused some industries to contract while inducing others to expand. Torvik (2001) also demonstrated that learning by doing can have differing effects on the productivity growth in the traded and nontraded goods sectors, and that a foreign exchange gift can cause currency appreciation. Using the Salter (1959) model of two goods, Nkusu (2004) showed that currency appreciation may not occur in the presence of unemployment. Taken as a whole, these empirical and simulation studies suggest that (1) development aid may not necessarily cause currency appreciation, and (2) aid may not necessarily cause deindustrialization of the export sector. Moreover, aid-induced Dutch disease does not imply that aid hurts the recipients.

Many less developing countries are also large exporters of only a few products and aid may affect their terms of trade. Ebrahim-zadeh (2003) noted that a coffee boom in Colombia caused currency appreciation and deindustrialization of the traditional export sectors. Also, the domestic price of nontraded goods may rise or fall, depending on its factor intensity and the response of factor prices. Prati and others (2003) analyzed the effect of sterilization in offsetting the adverse effect of currency appreciation and the ensuing deindustrialization.

\footnotetext{
${ }^{2}$ There are now some empirical studies of the Dutch disease. Spatafora and Warner (1999) show the presence of a weak Dutch disease from a resource boom, while Stijns (2003) demonstrates a strong Dutch disease effect. Specifically, Stijns shows that a 1 percent increase in energy exports results in an 8 percent decline in manufacturing exports. Benjamin and others (1989) constructed a CGE model of Cameroon and reported that a boom in the oil sector is likely to hurt the agricultural sector but benefit the manufacturing sector.
} 
The purpose of this paper is to analyze the impact of infrastructure aid on factor prices, output response, and welfare. Section II lays out the basic model of a small developing country that receives infrastructure aid. Section III considers the short-run output response and long-run effects on factor prices and the prices of nontraded goods, while Section IV delineates the conditions under which aid produces Dutch disease effects. Section V investigates the welfare effect of infrastructure aid and Section VI concludes.

\section{THE BASIC MODEL}

A substantial body of literature on the Dutch disease has been amassed since Corden and Neary (1982). They analyzed the effects of a resource boom using the two-factor, two-good model developed earlier by Salter (1959), but capital is a specific factor in each sector. In their framework, a resource boom causes currency appreciation, making the nontraded good more expensive. However, imports and exports are combined and treated as a single traded good, effectively constraining the domestic prices of traded goods to move together in most of their analysis. Adam and Bevan (2003) analyzed the effect of infrastructure capital in a two-period, Corden-Neary model.

Policymakers often are interested in the possible long-run Dutch disease effect of aid, and hence capital input should be treated as a mobile factor, rather than a specific factor as in Corden and Neary (1982). It is also necessary to separate the prices of traded goods in order to analyze the long-run effects on factor prices. In addition to the nontraded good, we thus assume there are two traded goods, and all three goods are produced using two factors, capital (K) and labor (L) inputs. This $3 \times 2$ model has been used previously in the literature (Cassing and Warr, 1985; Yano and Nugent, 1999; and Choi, 2003 and 2004).

To investigate the impact of foreign aid on the recipient, we employ the following assumptions:

(1) The recipient of aid is a small developing country, abundant in labor.

(2) Two primary factors (capital $K$ and labor $L$ ) are used to produce two traded goods, the exportable $Y_{1}$ and the importable $Y_{2}$, and a nontraded good $Y_{N}$.

(3) Factors are fully employed and are mobile among sectors. ${ }^{3}$

(4) Perfect competition prevails in both product and factor markets. ${ }^{4}$

\footnotetext{
${ }^{3}$ This assumption is far from the reality in many developing countries. However, if the unemployment rate is not affected by foreign aid, the results hold for the constant unemployment rate. Contrary to the traditional models, which assume a rising wage through exchange rate appreciation subsequent to an aid inflow, this model is designed to show differing wage effects at full employment or at constant frictional unemployment.

${ }^{4}$ This assumption essentially rules out monopoly in the product market and labor unions in the labor market but does not rule out frictional unemployment.
} 
(5) Infrastructure capital $S$ is a public good and cannot be appropriated by individual firms.

Let $A(S)$ denote the amount of aid required to install $S$ units of infrastructure capital. Infrastructure capital is a public good that cannot be appropriated by the private sectors. Infrastructure capital must be distinguished from private capital input. ${ }^{5}$ As in Adam and Bevan (2003), the government simply converts aid money into infrastructure capital $S$. However, it is not a direct transfer of physical capital equipment. The aid money is used to purchase domestic or foreign inputs to produce infrastructure capital. For instance, roads are constructed using construction equipment and domestic labor purchased through an aid transfer. Infrastructure investment often requires a long gestation period. For many years, even decades, the infrastructure sector diverts resources away from the production of other traded and nontraded goods and hence deindustrialization may result. We ignore these gestation period output effects in our analysis. ${ }^{6}$ Once the infrastructure is installed and operational, it will reduce the production costs of one or more industries.

Consider a developing country receiving foreign aid. The production possibility frontier (PPF) of a developing country is implicitly defined by $\phi\left(Y_{1}, Y_{2}, Y_{N}, K, L, S\right)=0$, where $Y_{i}$ is the output in sector $i$, and $K$ and $L$, respectively, denote fixed domestic supplies of private capital and labor. It is more convenient to use an explicit production possibility function:

$$
Y_{1}=F\left(Y_{2}, Y_{N}, K, L, S\right)
$$

Due to the lack of good roads, drinking water, and education, it is sometimes difficult for developing countries to adopt the new technologies used in developed economies. Infrastructure aid allows developing countries to switch from traditional methods to improved production technologies.

Consider a form of infrastructure aid that enhances productivity in only one sector. Infrastructure aid generally will raise consumer income and increase the demand for nontraded goods. In the process, the price of the nontraded goods also may be affected. To illustrate the long-run effects of infrastructure aid on traded goods, assume for simplicity's sake that the income effect on nontraded goods is zero. Figure 1 illustrates the case where the infrastructure investment lowers the production cost of the export sector. Infrastructure

\footnotetext{
${ }^{5}$ Infrastructure can be a global public good. For instance, an antimalarial drug is a global public good, which benefits not only the recipient but also the donor countries. Arrow (2004, p. 21) suggests that countries make "income transfers to poor countries" rather than subsidize "a particular good (antimalarial drugs or ACTS, in particular)" due to the inefficiency of imposing constraints on spending.

${ }^{6}$ The gestation period would correspond to period 1 in Adam and Bevan (2003). The results on possible Dutch disease effects during the gestation period can be obtained from the author.
} 
investment shifts the PPF outward from $A B$ to $A B_{1} B_{0}$. Since the recipient is a small country, terms of trade are fixed in the world market and domestic production will move to $B_{\mathrm{o}}$ and consumption to $F_{\mathrm{o}}$. The gap between the revenue lines, 0 and 0 ', shows the income gains from infrastructure investment. Since the export sector expands, there is no Dutch disease effect.

Developing countries often are large exporters of coffee, tea, organic food, and tropical products. If the recipient is a large exporter of good 1 , infrastructure aid will cause deterioration in the terms of trade, and the production point will move to the left of point $B$. If the terms of trade deteriorate slightly, production may move to a point like $B_{1}$, and this negative output effect does not fully offset the initial positive output effect of infrastructure investment.

If the terms of trade worsen considerably, it is possible for domestic production to move to a point like $B_{2}$, to the left of point $B$. In this case, it is the deterioration of the terms of trade that will cause a Dutch disease effect, reducing the output of the exportable.

Figure 1. Infrastructure Investment and Dutch Disease

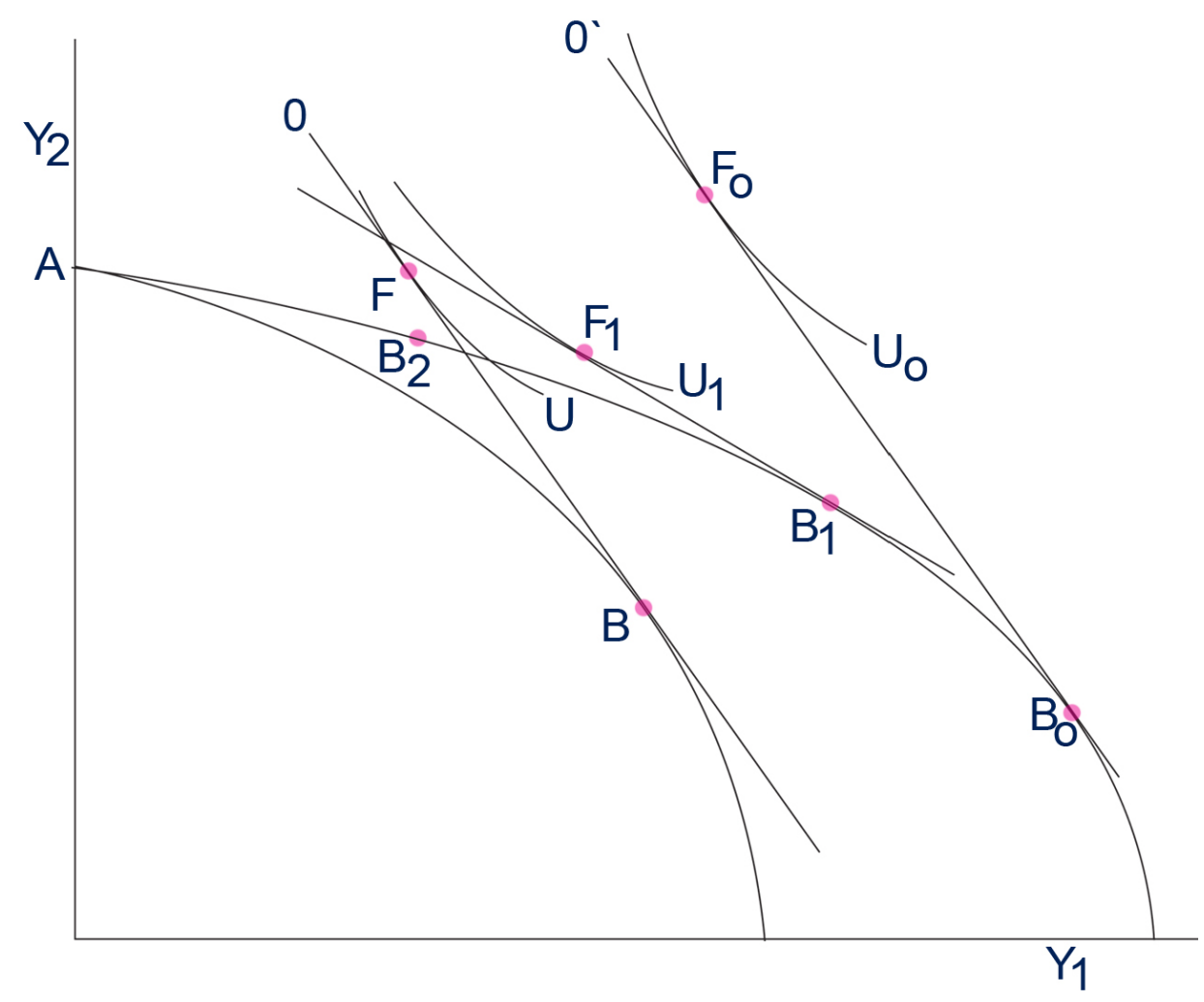




\section{Short-Term Effects of Infrastructure Investment on Production Costs}

Consider cost-saving infrastructure aid in the export sector. The long-run relationships between the prices of goods and factor prices are given by a zero profit condition: ${ }^{7}$

$$
\begin{gathered}
p_{1}=a_{L 1}(S) w+a_{K 1}(S) r \equiv g_{1}(w, r, S), \\
p_{2}=a_{L 2} w+a_{K 2} r \equiv g_{2}(w, r), \\
p_{N}=a_{L N} w+a_{K N} r \equiv g_{N}(w, r) .
\end{gathered}
$$

The per unit profit of the export sector is

$$
\pi_{1}=p_{1}-g_{1}(w, r, S)
$$

Let us take a snapshot of the developing economy immediately after the infrastructure capital is installed. In the short run, factor prices are fixed and unresponsive to infrastructure aid. Infrastructure investment, whether it saves labor- or capital, lowers unit cost in the targeted sector,

$$
\frac{\partial g_{1}}{\partial S}=\frac{\partial a_{L 1}}{\partial S} w+\frac{\partial a_{K 1}}{\partial S} r<0
$$

and increases the per unit profit $\pi_{1}$ of the export sector,

$$
\frac{\partial \pi_{1}}{\partial S}=-\frac{\partial g_{1}(w, r, S)}{\partial S}>0
$$

Thus, infrastructure investment in the export sector makes it more competitive and in the short run causes the sector to expand; this can be achieved by drawing more resources from other sectors. Whether it is targeted to improve productivity in the export, import or

\footnotetext{
${ }^{7}$ Once the infrastructure is installed, industry 1 operates with new input-output coefficients, but for convenience we use the same symbols here.
} 
nontraded goods sector, infrastructure investment eventually causes a realignment of the domestic wage and interest rates.

\section{Factor Prices and Exchange Rate}

In his seminal paper on the pattern of U.S. trade in 1947, Wassily Leontief (1953) suggested that the presence of better infrastructure in the United States made American workers more efficient than their foreign cohorts. Learning by doing can also reduce production costs. For instance, Torvik (2001) considered learning by doing to enhance labor productivity and lower labor costs in all sectors. In contrast, infrastructure aid can save capital or labor. To study the impact of infrastructure aid more systematically, we assume that infrastructure investment lowers production costs in a linear fashion. Specifically, we assume that one unit of infrastructure investment $S$ lowers labor and capital requirements by $\delta_{L j}$ and $\delta_{K j}$ units, that is,

$$
\begin{aligned}
& a_{L j}(w, r, S)=b_{L j}(w, r)-\delta_{L j} S, \\
& a_{K j}(w, r, S)=b_{K j}(w, r)-\delta_{K j} S .
\end{aligned}
$$

For example, in the absence of infrastructure investment, one unit of the exportable requires $b_{L 1}(w, r)$ units of labor and $b_{K 1}(w, r)$ units of capital, where $b_{L 1}(w, r)=a_{L 1}(w, r, 0)$ and $b_{K 1}(w, r)=a_{K 1}(w, r, 0)$. If one unit of infrastructure investment was made in the export sector, it reduces these input requirements to $a_{L 1}(w, r)=b_{L 1}(w, r)-\delta_{L 1}$ and $a_{K 1}(w, r)=b_{K 1}(w, r)-\delta_{K 1}$. In other words, the export industry with infrastructure has an absolute advantage over the same industry without infrastructure.

Infrastructure capital can affect productivity in all three sectors. The relationships between prices and outputs are given by

$$
\begin{aligned}
& p_{1}=\left(b_{L 1}-\delta_{L 1} S\right) w+\left(b_{K 1}-\delta_{K 1} S\right) r, \\
& p_{2}=\left(b_{L 2}-\delta_{K 2} S\right) w+\left(b_{K 2}-\delta_{K 2} S\right) r, \\
& p_{N}=\left(b_{L N}-\delta_{L N} S\right) w+\left(b_{K N}-\delta_{K N} S\right) r .
\end{aligned}
$$

First, consider the effect of infrastructure aid invested in the export $\operatorname{sector}\left(\delta_{L 1}>\delta_{L 2}=\delta_{L N}=0\right.$, and $\left.\delta_{K 1}>\delta_{K 2}=\delta_{K N}=0\right)$. Partially differentiating (1), allowing $w$ and $r$ to adjust but holding the world prices of traded goods constant, we get 


$$
\begin{aligned}
& \frac{\partial w}{\partial S}=\frac{\delta_{1} a_{K 2}}{\Delta}>0, \\
& \frac{\partial r}{\partial S}=-\frac{\delta_{1} a_{L 2}}{\Delta}<0 \\
& \frac{\partial p_{N}}{\partial S}=a_{L N} \frac{\partial w}{\partial S}+a_{K N} \frac{\partial r}{\partial S}=\delta_{1} a_{L 2} a_{L N}\left(k_{2}-k_{N}\right)>0
\end{aligned}
$$

where $\delta_{1} \equiv \delta_{L 1} w+\delta_{K 1} r=-\partial g_{1} / \partial S$ represents the reduction in unit cost of the exportable attributed to a one-unit increase in infrastructure investment. Thus, infrastructure investment in the export sector increases the wage rate but lowers the interest rate. Moreover, because $k_{2}>k_{N}>k_{1}$, infrastructure aid invested in the export sector raises the price of the nontraded good. While the terms of trade between the two traded goods are fixed in the world market, Corden and Neary's (1982) real exchange rate, $p_{N} / p_{2}$, appreciates, that is, ${ }^{8}$

$$
\frac{\partial\left(p_{N} / p_{2}\right)}{\partial S}>0
$$

Note also that the price of the nontraded good is unaffected when $k_{2}=k_{N}$. The greater the gap $\left(k_{2}-k_{N}\right)$, the higher the price of the nontraded good rises.

Next, consider the effect of infrastructure aid when invested in the import $\operatorname{sector}\left(\delta_{L 2}>\delta_{L 1}=\delta_{L N}=0\right.$, and $\left.\delta_{K 2}>\delta_{K 1}=\delta_{K N}=0\right)$. Then

$$
\begin{aligned}
& \frac{\partial w}{\partial S}=\frac{-\delta_{2} a_{K 1}}{\Delta}<0, \\
& \frac{\partial r}{\partial S}=\frac{\delta_{2} a_{L 1}}{\Delta}>0, \\
& \frac{\partial p_{N}}{\partial S}=a_{L N} \frac{\partial w}{\partial S}+a_{K N} \frac{\partial r}{\partial S}=\delta_{2} a_{L 1} a_{L N}\left(k_{N}-k_{1}\right)>0 .
\end{aligned}
$$

That is, cost-saving infrastructure investment in the import sector depresses the wage rate, but raises the interest rate and the cost of the nontraded good.

\footnotetext{
${ }^{8}$ Infrastructure aid in developing countries is predominantly spent on supplying drinking water, building roads, adding sewage systems, etc.
} 
Finally, assume that infrastructure aid is used only in the nontraded goods $\operatorname{sector}\left(\delta_{L N}>\delta_{L 1}=\delta_{L 2}=0\right.$, and $\left.\delta_{K N}>\delta_{K 1}=\delta_{K 2}=0\right)$. Recall that the prices of the two traded goods are set in the world market and they completely determine domestic factor prices. Thus, the wage and interest rates are unaffected by infrastructure aid. Differentiating $p_{N}$ in (2) with respect to $S$, holding factor prices constant, we obtain

$$
\begin{aligned}
& \frac{\partial p_{1}}{\partial S}=\frac{\partial p_{1}}{\partial S}=0, \\
& \frac{\partial p_{N}}{\partial S}=-\left(\delta_{L N} w+\delta_{K N} r\right)<0 .
\end{aligned}
$$

Accordingly, Corden and Neary's (1982) real exchange rate depreciates. This result contrasts with that of Adam and Bevan (2003), who reported that in their specific factors model, infrastructure aid in the nontraded goods sector has an ambiguous effect on the exchange rate.

Proposition 1: Assume $k_{2}>k_{N}>k_{1}$. In the short run when factor prices are fixed, labor- or capital-saving infrastructure investment in a sector increases its supply and profitability. In the long run, infrastructure investment in trade sectors causes a realignment of factor prices. Specifically,

(1) infrastructure aid in the export sector raises the domestic wage rate and the cost of the nontraded goods, but lowers the interest rate, and causes an appreciation of the Corden-Neary (1982) real exchange rate,

(2) infrastructure aid in the import sector has the opposite effects on factor prices but causes an appreciation of the real exchange rate, and

(3) infrastructure aid in the nontraded goods sector has no effect on factor prices but causes a depreciation of the real exchange rate.

Infrastructure aid enhances productivity and causes a boom in the targeted sector in the short run. Thus, one might expect a Dutch disease-like effect in the agricultural sector. However, the Dutch disease in Corden and Neary (1982) follows an exchange rate appreciation and a subsequent increase in the wage rate. This proposition shows that infrastructure aid raises the wage rate only when targeted in the export sector. ${ }^{9}$ The real exchange rate appreciates,

\footnotetext{
${ }^{9}$ Proposition 1 can easily be adapted for developed economies whose exports are capital intensive as in the learning-by-doing literature. In this case, given $k_{2}>k_{N}>k_{1}$, industry 2 is the export sector, and part (1) reads: Infrastructure aid in industry 1 (the labor-intensive sector) raises the domestic wage rate and the cost of the nontraded goods but lowers the interest rate, and causes an appreciation of the real exchange rate. For
} 
whether infrastructure aid is used in the import or export sector. However, infrastructure aid in the nontraded goods sector unambiguously causes a depreciation of the exchange rate.

This result is in stark contrast to Corden and Neary (1982) and Adam and Bevan (2003) in which domestic prices of traded goods are constrained to move together at all times and capital is a fixed factor in all three sectors. In this model, capital and labor are both mobile factors. Infrastructure aid in the export sector lowers production costs and creates a tension between domestic costs and prices, which is resolved by a boom in that sector, drawing resources from other sectors. ${ }^{10}$ This pull causes a realignment of factor prices, and continues until a new set of factor prices reestablishes a new equilibrium in which all sectors earn zero profits. Positive profits that may accrue to the targeted industry in the short run will soon be eliminated. Thus, infrastructure aid requires an eventual adjustment in domestic factor prices. The wage rate rises only when infrastructure aid is targeted in the export sector, but the exchange rate appreciates whether the wage rate rises or falls.

Infrastructure aid in the import sector raises its productivity but lowers the domestic wage rate. This is the opposite of the Balassa-Samuelson effect that productivity growth in traded goods raises the wage rate and prices of nontraded goods. In their model, there are only two goods as in Salter, and internationally mobile capital ensures that interest rate is fixed in the world market. Accordingly, productivity growth in the tradable sector raises the wage rate. The present model is more relevant for analyzing the impacts of infrastructure aid on developing countries, where interest rates tend to be higher than in developed economies.

Moreover, even though world prices are held constant, the productivity shocks induced by infrastructure aid produce Stolper-Samuelson-like effects because changes in costs or prices affect domestic factor prices. For instance, infrastructure aid in a sector which reduces its production costs produces qualitatively the same effects on factor prices as an increase in its price, although the magnitudes of such changes will be different.

\section{Infrastructure Aid and Externality}

Infrastructure investment may not have cost-saving effects on all industries. Realistically, infrastructure investment intended to lower production costs in one sector may cause a negative externality and raise production costs in another sector. For instance, a new dam built by aid money may divert water and help the manufacturing sector, but at the same time may increase the production costs of farming or fishery.

instance, infrastructure investment in the Japanese agriculture will only raise Japanese wage and the cost of Japan's nontraded goods.

10 This tension also can be resolved, for instance, when an import or export tariff is imposed to fill the gap between the world price and domestic unit cost. In this case, factor prices will be unaffected. 
Figure 2. Infrastructure Investment with Negative Externality

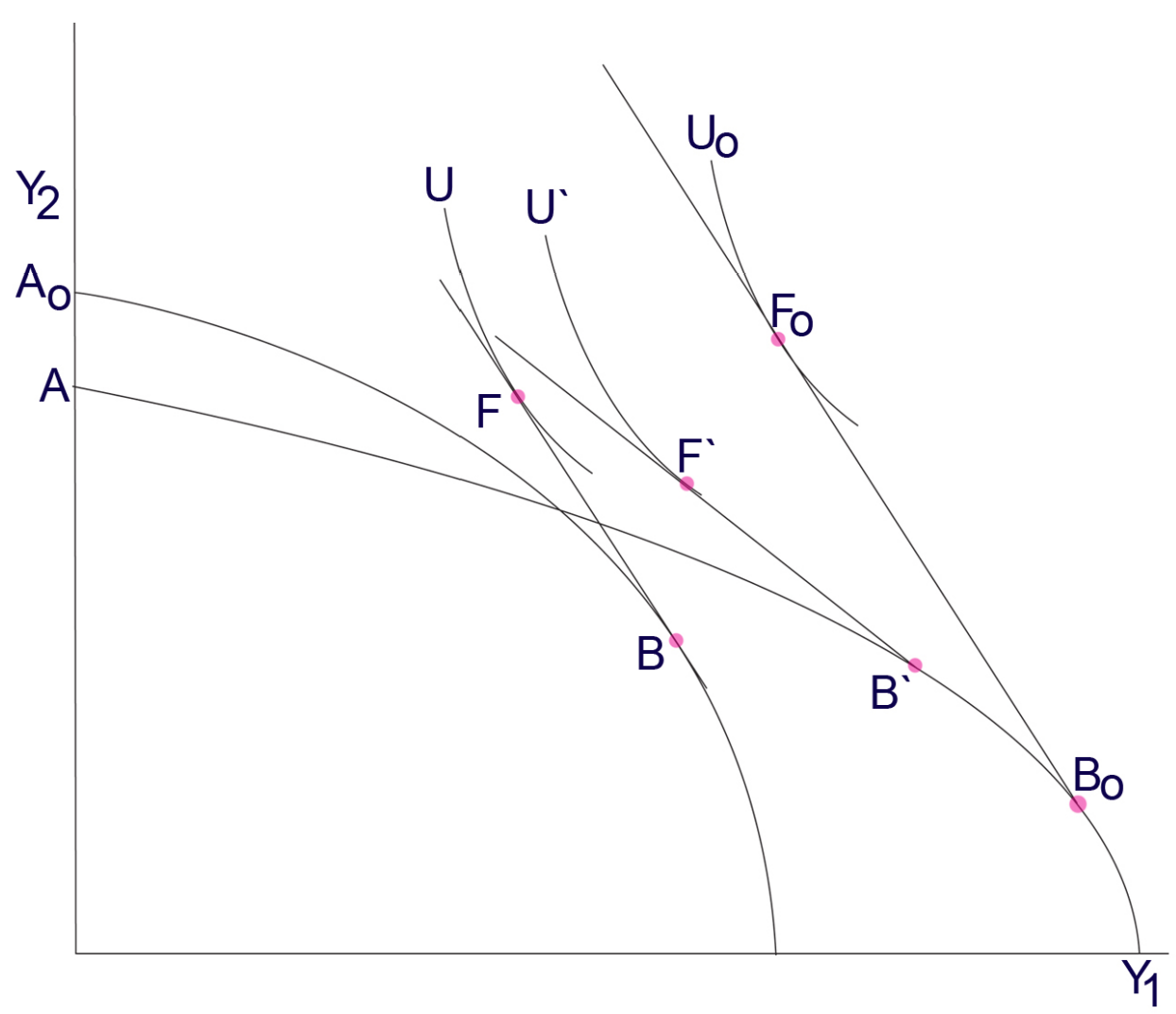

Figure 2 illustrates the case where infrastructure investment intended to lower the cost of the importable causes a negative externality and raises production costs in the import sector. Such a situation may arise when $\delta_{L 1}>0>\delta_{L 2}$ or $\delta_{K 1}>0>\delta_{K 2}$. In the initial equilibrium, production occurs at point $B$ and consumption at $F$. Infrastructure investment shifts the frontier $A B$ to $A_{0} B_{0}$. If the recipient is a small country, prices are fixed in the world market, and production will occur at point $B_{\mathrm{o}}$, which shows a substantial boom in the export sector and deindustrialization in the manufacturing sector. If the recipient is a large exporter of a tropical product, such a boom in the export sector may worsen rather than improve the terms of trade, shifting production to $B^{\prime}$ and consumption to $F$. At point $B$, the induced worsening of the terms of trade partly offsets deindustrialization in the import sector, but it also could more than offset it.

We now consider the effect of infrastructure aid with a negative externality on factor prices. Recall from (2) and (3) that cost-saving infrastructure aid in the import sector has the opposite effect on domestic factor prices as that aid in the export sector. Thus, a negative externality reinforces the effects on domestic factor prices of cost-saving infrastructure aid in the absence of the externality. On the other hand, if infrastructure aid produces a positive externality, the net effect becomes ambiguous. 


\section{When Aid Causes Dutch Disease}

In this section we focus on the supply side or the output effects of infrastructure investment. Aid-financed infrastructure investment in the export sector affects not only outputs in the short run, but also outputs of the three sectors in the long run when both capital and labor are mobile inputs.

Once the infrastructure is installed, the export sector uses lesser amounts of inputs, thereby shifting the PPF outward in Figure 1. Optimal outputs of traded goods can then be written as $Y_{1}\left(p_{1}, p_{2}, K, L, S\right)$ and $Y_{2}\left(p_{1}, p_{2}, K, L, S\right)$. Also, infrastructure investment raises consumer income, which in turn increases the output of the nontraded good, and hence it may be written as $Y_{N}\left(p_{1}, p_{2}, K, L, S\right)$.

Infrastructure investment makes some industries more competitive and in the process raises national income, which in turn increases the consumption of all goods, including the nontraded good. Thus, infrastructure investment will have an income effect on the consumption and production of the nontraded good. This induced increase in demand for the nontraded good necessarily reduces the amounts of capital and labor inputs available for the production of the traded goods. Thus, production of the traded goods satisfies the constraints,

$$
\begin{aligned}
& \left(b_{L 1}-\delta_{L 1} S\right) Y_{1}+\left(b_{L 2}-\delta_{L 2} S\right) Y_{2}=L-a_{L N} Y_{N}, \\
& \left(b_{K 1}-\delta_{K 1} S\right) Y_{1}+\left(b_{K 2}-\delta_{K 2} S\right) Y_{2}=K-a_{K N} Y_{N} .
\end{aligned}
$$

Does the infrastructure investment make the targeted sector more capital intensive? If it is only labor saving $\left(\delta_{L 1}>0\right)$, then infrastructure investment makes the industry less labor intensive or more capital intensive. On the other hand, if it saves only capital $\left(\delta_{K 1}>0\right)$, then it makes the industry less capital intensive. ${ }^{11}$

We now consider the output effects of labor- and capital-saving infrastructure aid. Let the second subscript denote that a partial derivative is taken with respect to that variable. Differentiating (5) with respect to $S$ gives

\footnotetext{
${ }^{11}$ If it saves both capital and labor, we can compare the capital intensities of the export sector before and after the infrastructure investment:

$$
\frac{b_{K 1}-\delta_{K 1} S}{b_{L 1}-\delta_{L 1} S}-\frac{b_{K 1}}{b_{L 1}}=\frac{\delta_{L 1}}{b_{L 1}-\delta_{L 1} S}\left(\frac{b_{K 1}}{b_{L 1}}-\frac{\delta_{K 1}}{\delta_{L 1}}\right), \quad \delta_{L 1} \neq 0 .
$$

Thus, the export industry becomes more capital intensive if $b_{K 1} / b_{L 1}>\delta_{K 1} / \delta_{L 1}$.
} 


$$
\begin{aligned}
& \frac{\partial Y_{1}}{\partial S}=\frac{1}{\Delta}\left(a_{K 2}\left(\delta_{L}-a_{L N} Y_{N S}\right)-a_{L 2}\left(\delta_{K}-a_{K N} Y_{N S}\right)\right), \\
& \frac{\partial Y_{2}}{\partial S}=\frac{1}{\Delta}\left(a_{L 1}\left(\delta_{K}-a_{K N} Y_{N S}\right)-a_{K 1}\left(\delta_{L}-a_{L N} Y_{N S}\right)\right),
\end{aligned}
$$

where $Y_{N S} \equiv \partial Y_{N} / \partial S$, and $\delta_{L}=\delta_{L 1} Y_{1}+\delta_{L 2} Y_{2}=\partial L_{1} / \partial S+\partial L_{2} / \partial S$ represents labor saving, factor prices being held constant, that is attributable to a one unit increase in infrastructure aid, while $\delta_{K}=\delta_{K 1} Y_{1}+\delta_{K 2} Y_{2}=\partial K_{1} / \partial S+\partial K_{2} / \partial S$ is capital saved from one unit of infrastructure aid. These equations show that the direction of output changes is not affected by whether infrastructure investment involves the export or the import sector.

Consider first the effect of infrastructure investment that enhances only the labor productivity of either the export sector or the import sector $\left(\delta_{L}>0, \delta_{K}=0\right) .{ }^{12}$ Then

$$
\begin{aligned}
& \frac{\partial Y_{1}}{\partial S}=\frac{1}{\Delta}\left(a_{K 2} \delta_{L}-a_{L 2} a_{L N} Y_{N S}\left(k_{2}-k_{N}\right)\right), \\
& \frac{\partial Y_{2}}{\partial S}=\frac{1}{\Delta}\left(-a_{K 1} \delta_{L}-a_{L 1} a_{L N} Y_{N S}\left(k_{N}-k_{1}\right)\right) .
\end{aligned}
$$

If the income effect on the nontraded good is zero, then $Y_{N S} \equiv X_{N I}(\partial I / \partial S)=0$, and $\partial Y_{1} / \partial S>0$ and $\partial Y_{2} / \partial S<0$. That is, regardless of the affected sectors, labor-saving infrastructure investment increases the output of the labor-intensive industry and decreases that of the capital-intensive industry. If the nontraded good is normal $\left(X_{N I}>0\right)$, the aidinduced increase in the production of the nontraded good reduces the outputs of traded goods. Specifically, the income effect on the nontraded good partly offsets the expansion in the export sector, but further reinforces the contraction of the import sector.

This result of labor-saving infrastructure aid is reminiscent of the celebrated Rybczynski Theorem that an increase in labor supply increases the output of the labor-intensive sector and decreases that of the import sector. Thus, labor-saving infrastructure investment has the same qualitative effects on outputs as an increase in labor supply. Intuitively, in the presence of labor-saving infrastructure, each labor unit becomes more efficient and is equivalent to a larger unit without the infrastructure investment.

\footnotetext{
${ }^{12}$ It can be shown that in general if infrastructure investment makes the export sector more capital intensive $\left(b_{K 1} / b_{L 1}>\delta_{K 1} / \delta_{L 1}\right)$ and the income effect on the nontraded good is zero, then

$\partial Y_{1} / \partial S=a_{L 2} \delta_{L 1}\left(a_{K 2} / a_{L 2}-\delta_{K 1} / \delta_{L 1}\right) / \Delta>0$ and $\partial Y_{2} / \partial S=a_{L 1} \delta_{L 1}\left(\delta_{K 1} / \delta_{L 1}-a_{K 1} / a_{L 1}\right) / \Delta<0$.
} 
Next, assume that infrastructure investment enhances only the capital productivity $\left(\delta_{L}=0, \delta_{K}>0\right)$.

$$
\begin{aligned}
& \frac{\partial Y_{1}}{\partial S}=\frac{1}{\Delta}\left(-\delta_{K} a_{L 2}-Y_{N S} a_{L N} a_{L 2}\left(k_{2}-k_{N}\right)\right), \\
& \frac{\partial Y_{2}}{\partial S}=\frac{1}{\Delta}\left(\delta_{K} a_{L 1}-Y_{N S} a_{L N} a_{L 1}\left(k_{N}-k_{1}\right)\right) .
\end{aligned}
$$

If the income effect on the nontraded good is zero, $\partial Y_{1} / \partial S<0$ and $\partial Y_{2} / \partial S>0$. The negative income effect will partly offset the expansion in the import sector while it reinforces the contraction in the export sector.

Proposition 2: Assume that the import sector is capital intensive $\left(k_{2}>k_{1}\right)$ and that the income effect on the nontraded good is zero $\left(X_{N I}=0\right)$. Regardless of the sectors affected, labor-saving infrastructure aid increases the output of the export sector but causes deindustrialization in the import sector. On the other hand, a capital-saving infrastructure investment causes a contraction of the export sector but increases the output of the import sector.

Intuitively, this proposition states that a labor-(capital-)saving infrastructure investment increases the output of the sector that intensively uses that factor and causes a deindustrialization of the other sector. This proposition clearly predicts when infrastructure aid will cause a Dutch disease effect. If the nontraded goods sector is held constant, $a$ capital-saving infrastructure investment has a deindustrialization effect on the laborintensive industry - which is the export sector of developing countries. On the other hand, $a$ labor-saving infrastructure investment causes a contraction or deindustrialization of the capital-intensive sector. It does not matter whether infrastructure investment lowers production costs of the export or of the import sector.

If the income effect is positive, the induced increase in the consumption of the nontraded good decreases the amounts of capital and labor inputs available for the production of the traded goods, and causes a contraction in both trade sectors. This secondary effect partly offsets the initial expansion of the export sector. While the total effect is generally indeterminate, in practice, infrastructure aid designed to lower production costs in the export sector necessarily increases its output despite the secondary offsetting effect of the expanding nontraded goods sector. On the other hand, the induced expansion of the nontraded goods sector further reinforces the deindustrializing effect on the import sector.

Proposition 2 has an important policy implication in developing countries. Given the choice between labor- or capital-saving technologies, if the goal is to maintain or expand agricultural exports, scarce foreign aid should be used for labor-saving, rather than capitalsaving, infrastructure investment. In an attempt to conserve scarce capital inputs, 
governments in developing countries may be tempted to invest in infrastructure to reduce the wear and tear of capital equipment. Such a policy tends to benefit the import sector, which uses capital intensively, but causes a deindustrialization in the export sector. On the other hand, capital-saving infrastructure aid may cause so much expansion of the manufacturing sector that the developing country may reverse its traditional trade pattern and become a newly industrializing country that exports manufactured goods. Continued capital-saving aid will further expand its manufacturing sector and contract the agricultural sector.

This result is in contrast to the Dutch disease effect in Matsuyama (1992). In an open economy, productivity growth in agriculture "squeezes out" manufactures and may cause deindustrialization. In the present model, it is the labor-saving innovations as embodied in infrastructure aid, whether directed toward agriculture or manufacturing, that squeeze out manufacturing.

Next, assume that infrastructure aid saves both capital and labor. Then (6) can be written:

$$
\begin{aligned}
& \frac{\partial Y_{1}}{\partial S}=\frac{1}{\Delta}\left(a_{L 2} \delta_{L}\left(k_{2}-k_{\delta}\right)-a_{L 2} a_{L N} Y_{N S}\left(k_{2}-k_{N}\right)\right), \\
& \frac{\partial Y_{2}}{\partial S}=\frac{1}{\Delta}\left(a_{L 1} \delta_{L}\left(k_{\delta}-k_{1}\right)-a_{L 1} a_{L N} Y_{N S}\left(k_{N}-k_{1}\right)\right),
\end{aligned}
$$

where $\delta_{k} \equiv \delta_{k} / \delta_{L}$ represents the ratio of saved capital to saved labor. The saved amounts of capital and labor are equivalent to increases in factor endowments. If infrastructure investment is neutral $\left(k=k_{\delta}\right)$, infrastructure saves both factors equiproportionately. If infrastructure aid is mostly labor saving, $k_{\delta}$ approaches zero. On the other hand, if it saves mostly capital, then $k_{\delta}$ diverges to infinity.

Proposition 3: Assume that infrastructure investment $S$ saves both capital and labor and that the income effect on the nontraded good is zero. Then

(i) If $k_{2}>k_{\delta}\left(k_{2}<k_{\delta}\right)$, then $\partial Y_{1} / \partial S>0\left(\partial Y_{1} / \partial S<0\right)$, and

(ii) If $k_{\delta}>k_{1}\left(k_{\delta}<k_{1}\right)$, then $\partial Y_{2} / \partial S>0\left(\partial Y_{2} / \partial S<0\right)$.

This proposition suggests the possibility that infrastructure aid increases the output of both sectors, especially when it is neutral and saves both capital and labor inputs equiproportionately. Thus, capital- and labor-saving infrastructure aid results in a more balanced growth of both trade sectors. 


\section{Price Response ANd Welfare EfFects}

In this section, we focus on consumer income and the welfare effect of labor-saving infrastructure aid. Propositions 2 and 3 delineating the possible Dutch disease effects of infrastructure aid in the previous section are based on the simplifying assumption that the income effect on the nontraded good is zero. Any income effect will either strengthen or offset these output effects on the export and import sectors. If infrastructure aid increases consumer income, it also will increase the demand for the nontraded good.

In a two-factor framework, the prices of the two traded goods completely determine the factor prices, $w$ and $r$, hence they can be written as $w\left(p_{1}, p_{2}\right)$ and $r\left(p_{1}, p_{2}\right)$. Then the price of the nontraded good can be written as a function of the prices of traded goods, $p_{N}\left(p_{1}, p_{2}\right)$. The supply of the nontraded good must satisfy an additional constraint,

$$
Y_{N}=X_{N}\left(p_{1}, p_{2}, p_{N}, I\right)
$$

where $I$ is consumer income and $X_{N}\left(p_{1}, p_{2}, p_{N}, I\right)$ is demand for the nontraded good to be derived shortly. Recall from (7) that infrastructure aid affects consumer income, which alters the amounts of factors available for traded goods. We now assume that the income effect on the nontraded good is either zero or negligible so that the direction of output responses remains unaffected, that is, $\partial Y_{1} / \partial S>0$ and $\partial Y_{2} / \partial S<0$.

Assume that the recipient must pay a small fraction $\alpha$ each year to pay off the loan. After deducting the loan payment, producer revenue is

$$
R=p_{1} F\left(Y_{2}, K, L, S\right)+p_{2} Y_{2}+p_{N} Y_{N}-\alpha A(S),
$$

where $\alpha A(S)$ is the annual cost of borrowing or loan repayment. It can be shown that if the donor chooses an insufficient amount, $\partial R / \partial S>0 .^{13}$

\footnotetext{
${ }^{13}$ From (10), we get
}

$$
\frac{\partial R}{\partial S}=p_{1} Y_{1 S}+p_{2} Y_{2 S}+p_{N} Y_{N S}+Y_{N} p_{N S}-\alpha A^{\prime} .
$$

Note that $p_{1} Y_{1 S}+p_{2} Y_{2 S}+p_{N} Y_{N S}+Y_{N} p_{N S}$ is the marginal revenue of infrastructure investment, allowing an induced change in the price of the nontraded good, and $\alpha_{A}{ }^{\prime}(S)$ is the marginal cost of borrowing. World prices of the traded goods, $p_{1}^{*}$ and $p_{2}^{*}$, are fixed in the world market, but infrastructure investment necessarily causes a realignment of factor prices and the price of the nontraded good. If the recipient were allowed to choose the aid level, the marginal return of aid would be zero. However, the donor country almost always chooses an insufficient amount for the recipient. In this situation, labor-saving infrastructure investment necessarily raises total producer income, that is, $\partial R / \partial S>0$. 
We now consider the demand side. Producer revenue is distributed to consumers in the form of wage and interest income. Consumer income is producer revenue plus tariff revenue, less debt payment. Consumers are assumed to maximize utility $U\left(X_{1}, X_{2}, X_{N}\right)$ subject to the budget constraint, $I=p_{1} X_{1}+p_{2} X_{2}+p_{N} X_{N}$. Demand functions for the two traded goods are generally written as: $X_{i}=h_{i}\left(p_{1}, p_{2}, p_{N}, I\right)$. Consumer income and indirectly utility are written as

$$
\begin{aligned}
& I \equiv\left[p_{1} F\left(Y_{2}, Y_{N}, K, L, S\right)+p_{2} Y_{2}+p_{N} Y_{N}+t Q-\alpha A(S)\right] \\
& V\left(p_{1}, p_{2}, p_{N}, I\right)=U\left(X_{1}\left(p_{1}, p_{2}, p_{N}, I\right), X_{2}\left(p_{1}, p_{2}, p_{N}, I\right), X_{N}\left(p_{1}, p_{2}, p_{N}, I\right)\right) .
\end{aligned}
$$

The government collects tariff revenue,

$$
G=t Q
$$

where $Q$ is import demand to be defined shortly. Following the tradition, we assume that tariff revenue is rebated to consumers.

\section{Import Demand and Consumer Income}

Recall that in addition to revenue from production, consumers receive a tariff rebate, which affects import demand, and the latter in turn affects consumer income. Thus, consumer income and import demand are jointly determined,

$$
\begin{gathered}
I \equiv R+t Q=p_{1} F\left(Y_{2}, K, L, S\right)+p_{2} Y_{2}+p_{N} Y_{N}+t Q-\alpha A(S) \\
Q\left(p_{1}, p_{2}, p_{N}, I\right) \equiv X_{2}\left(p_{1}, p_{2}, p_{N}, I\right)-Y_{2}\left(p_{1}, p_{2}, K, L, S\right)
\end{gathered}
$$

which implies $Q_{I}=X_{2 I} \equiv \partial X_{2} / \partial I$. Assume that all goods are normal, that is, $X_{1 I} \geq 0, X_{2 I} \geq 0$, and $X_{N I} \geq 0$. Differentiating (12) and (13) with respect to $\mathrm{S}$ and rearranging the terms, we obtain

$$
\frac{\partial I}{\partial S}=\frac{R_{S}+t\left(X_{2 S}-Y_{2 S}\right)}{1-t X_{2 I}}=\frac{R_{S}^{*}+t X_{2 S}}{1-t X_{2 I}},
$$




$$
\frac{\partial Q}{\partial S}=\frac{X_{2 I} R_{S}+\left(X_{2 S}-Y_{2 S}\right)}{1-t X_{2 I}}
$$

where $R_{s}^{*} \equiv\left(p_{1} Y_{1 S}+\left(p_{2}-t\right) Y_{2 S}+p_{N} Y_{N S}-\alpha A^{\prime}\right)+Y_{N} p_{N S}$ represents marginal return from aid evaluated at world prices, which also should be positive; $X_{2 S} \equiv X_{2 N} p_{N S}$ is the effect of infrastructure aid on the demand for the importable though a change in the price of the nontraded good, and $Y_{2 S} \equiv \partial Y_{2} / \partial S<0$. We assume that the nontraded good is a substitute for traded goods $\left(X_{2 N} \equiv \partial X_{2} / p_{N}>0\right)$. Then infrastructure aid increases demand for the importable, $X_{2 S}>0$. Recall that $R_{S} \equiv \partial R / \partial S>0$ because of the assumption that aid falls short of the optimal level. ${ }^{14}$ Note also that marginal propensity to consume the importable $p_{2} X_{2 I}$ is less than unity. Because $p_{2}>t, 1-t X_{2 I}>0$. Since $R_{S}^{*}>0$, and $X_{2 S}>0$ for capitalor labor-saving infrastructure aid, $\partial I / \partial S>0$. On the other hand, the sign of $\partial Q / \partial S$ is positive for labor-saving infrastructure aid, but is indeterminate for capital-saving aid.

Proposition 4: Assume that the marginal return from infrastructure aid evaluated at world prices is positive $\left(R_{S}^{*}>0\right)$. Then regardless of the sign of $Q_{S}$, any capital- or labor-saving infrastructure aid increases consumer income.

\section{Welfare Effect}

Consider the effect of infrastructure investment that only lowers the cost of the exportable as in Proposition 2. The indirect utility function is written as

$$
J\left(p_{1}, p_{2}, p_{N}, I\right) \equiv V\left[p_{1}, p_{2}, p_{N}, p_{1} F\left(Y_{2}, K, L, S\right)+p_{2} Y_{2}+p_{N} Y_{N}+t Q-\alpha A(S)\right] .
$$

Note that infrastructure investment affects both the price of the nontraded good and consumer income. Let $V_{I} \equiv \partial V / \partial I$ denote marginal utility of income. Differentiating (16) with respect to $S$ and using Roy's identity, $V_{i} \equiv \partial V / \partial p_{i}=-V_{I} X_{i}$, we obtain:

$$
\frac{\partial J}{\partial S}=\left(V_{N} \frac{\partial p_{N}}{\partial S}+V_{I} \frac{\partial I}{\partial S}\right)=V_{I}\left(-X_{N} p_{N S}+I_{S}\right)=V_{I} I_{S}^{o},
$$

\footnotetext{
${ }^{14}$ It is well known that in a multiperiod framework, consumption smoothing is optimal. Gupta and others (2004) report that even food aid was insufficient to mitigate contemporaneous food shortages; this is an indication that aid did not reach the optimal level from the recipient's perspective.
} 
where $I_{S} \equiv \partial I / \partial S$ allows induced changes in the price of the nontraded good, and $I_{S}^{o} \equiv I_{S}-Y_{N} p_{N S}$, which is assumed to be positive, measures the effect of aid on income when $p_{N}$ is held constant.

Proposition 5: Assume that infrastructure aid increases consumer income when the price of the nontraded good is held constant $\left(I_{S}^{o} \equiv p_{1} Y_{1 S}+p_{2} Y_{2 S}+p_{N} Y_{N S}+t Q_{S}-\alpha A^{\prime}>0\right)$. Then laboror capital-saving infrastructure aid improves consumer welfare, $\partial J / \partial S>0$, regardless of the induced change in the price of the nontraded good.

To get a rough idea of the welfare effects of infrastructure aid, first consider the case where the tariff rate is zero. Recall that when trade is not restricted $(t=0)$,

$I=R-\alpha A(S)$, and $I_{S}=R_{S}$ in(14). Thus, infrastructure aid increases consumer income. Next, for labor-saving infrastructure aid, $Y_{2 S}<0$ and $Q_{S}>0$ in (15). Thus, consumer welfare definitely increases. For capital-saving infrastructure aid, the sign of $Q_{S}$ is indeterminate. Even when the tariff rate is positive, tariff revenue is a very small fraction of consumer income. Whether the tariff revenue increases or declines, if infrastructure aid increases consumer income, and the price of the nontraded good is constant $\left(I_{S}^{o}>0\right)$, even capitalsaving infrastructure aid improves consumer welfare.

\section{CONCLUding ReMARKS}

This paper considers possible Dutch disease effects of infrastructure aid in developing countries. While it is possible to consider infrastructure aid to large developing countries such as India and China, the majority of the recipients of development aid are small countries. Thus, infrastructure aid is not likely to affect the world prices of goods developing countries import and export. The very need for infrastructure aid evidenced by lack of drinking water, education, and good roads suggests that production is inefficient in developing countries. Infrastructure aid lowers the production cost in the targeted industry and in the long-run forces a realignment of domestic factor prices. Our analysis shows that infrastructure aid to a sector raises the price of the factor intensively used in that sector. Thus, infrastructure aid in the export sector that uses the recipient's abundant factor raises the domestic wage rate. On the other hand, infrastructure aid targeting the import sector lowers the domestic wage rate, and that in the nontraded goods sector has no effect on the wage rate.

Infrastructure aid lowers production costs and makes the targeted industry more competitive. This improved production efficiency also requires a long-run adjustment in outputs, but the output adjustment does not depend on which industry aid is targeted. Rather, output adjustment depends on whether infrastructure aid saves labor or capital. The output effects of labor-saving infrastructure aid are similar to those of an increase in labor endowment. Thus, labor-saving infrastructure aid causes an expansion in the labor-intensive agriculture sector, and a contraction or deindustrialization in the manufacturing sector. On the other hand, 
capital-saving infrastructure causes a Dutch disease or deagriculturalization in the export sector but an expansion of the capital-intensive manufacturing sector.

The Dutch disease effects in the literature are caused by the rising wage rate and subsequent exchange rate appreciation. This paper demonstrates that infrastructure aid can cause deindustrialization of the export sector, independent of its effects on the wage rate and the interest rate. Propositions 1 and 2 have striking implications for developing countries: (1) labor-saving infrastructure aid in the export sector causes an expansion in that sector and a contraction of the import sector, and raises the wage rate and lowers the interest rate, while (2) capital-saving aid in the export sector causes its contraction — an unintended Dutch disease effect - and an expansion of the import sector, at the same time raising the wage rate and lowering the interest rate.

On the other hand, (3) labor-saving aid in the import sector causes an expansion of the export sector but a contraction of the import sector, lowering the wage rate and raising the interest rate simultaneously, whereas (4) capital-saving aid in the import sector causes it to expand and the export sector to contract — another Dutch disease like effect—despite the falling wage rate and the rising interest rate that occur concurrently.

Capital-saving aid in the export sector intended to stimulate it will have an unintended contraction in that sector, because the saved capital causes a reallocation of capital among the three sectors, ultimately resulting in a deindustrialization of the labor-intensive export sector. Similarly, capital-saving aid in the import sector intended to stimulate its growth will paradoxically cause a Dutch disease like deindustrialization in that sector, because it loses resources to others in the reallocation process, despite the falling wage rate.

Moreover, labor-saving aid invested in the export sector raises the wage rate, rather than relieving the pressure on the wage rate. Similarly, capital-saving aid poured into the import sector intended to relieve the pressure on the interest rate has the opposite effect.

These results have practical policy implications. If the primary concern is wage stability, infrastructure aid should be used in the nontraded goods sector. If the recipient's goal is to strengthen manufacturing and encourage a newly industrializing country, aid money should be used to acquire capital-saving infrastructure and deagriculturalization is not to be feared. For instance, good roads make capital equipment last longer and increase the output of the capital-intensive sector, but hospitals and drinking water improve the health of laborers and expand domestic food supply. If deindustrialization of any sector is to be avoided, capitaland labor-saving infrastructure can be built with the aid money. If infrastructure aid saves both capital and labor, both industries will expand.

Regardless of possible contraction in the export sector, the ultimate question is whether the recipient benefits from infrastructure aid. Whether marginal return from infrastructure aid is positive depends on whether a developing country has received an optimal amount of infrastructure aid. Marginal return from infrastructure aid will become negative beyond this 
amount. However, for the majority of developing countries that are beset with famine, AIDS, lack of drinking water, etc., marginal return from infrastructure aid is positive for all practical purposes. High-income countries tend to enjoy high income because among other reasons they have invested more infrastructure capital. 


\section{References}

Adam, Christopher S., and David L. Bevan, 2003, “Aid, Public Expenditure and Dutch Disease," Centre for the Study of African Economies Working Paper No. 2003-02 (Oxford: University of Oxford).

Arrow, Kenneth J., 2004, "New Antimalarial Drugs: Biology and Economics Meet," Finance \& Development, Vol. 41 (March), pp. 20-21.

Bandara, Jayatilleki S., 1995, “The Dutch Disease in a Developing Country: The Case of Foreign Capital Inflow to Sri Lanka," Seoul Journal of Economics, Vol. 8 (Fall), pp. 311-29.

Benjamin, Nancy C., Shantayanan Devarajan, and Robert J. Weiner, 1989, “The 'Dutch' Disease in a Developing Country: Oil reserves in Cameroon," Journal of Development Economics, Vol. 30 (January), pp. 71-92.

Cassing, James H., and Peter G. Warr, 1985, “The Distributional Impact of a Resource Boom,” Journal of International Economics, Vol. 18 (May), pp. 301-19.

Choi, E. Kwan, 2003, "Implications of Many Industries in the Heckscher-Ohlin Trade Model," in (s.), Handbook of International Trade, ed. by Choi and James Harrigan (Malden, Massachusetts: Blackwell Publishing).

Choi, E. Kwan, 2004, "Aid Allocation and the Transfer Paradox in Small Open Economies," International Review of Economics and Finance, Vol. 13, No. 3, pp. 245-51.

Corden, W. Max, and Neary, J. Peter, 1982, "Booming Sector and De-Industrialisation in a Small Open Economy," The Economic Journal, Vol. 92 (December), pp. 825-48.

Ebrahim-zadeh, Christine, 2003, "Dutch Disease: Too Much Wealth Managed Unwisely," Finance \& Development, Vol. 40 (March), pp. 50-51.

Elbadawi, Ibrahim, 1999, "External Aid: Help or Hindrance to Export Orientation in Africa?” Journal of African Economies, Vol. 8 (December), pp. 578-616.

Gupta, Sanjeev, Benedict Clements, and Erwin Tiongson, 2004, "Foreign Aid and Consumption Smoothing: Evidence from Global Food Aid," Review of Development Economics, Vol. 8 (August), pp. 379-90.

Leontief, Wassily W., "Domestic Production and Foreign Trade: the American Capital Position Re-examined," Proceedings of the American Philosophical Society 97 (1953), pp. 332-49. Reprinted in R. E. Caves and H. G. Johnson (ed.), American Economic Association, Readings in International Economics (Homewood, Illinois: Richard D. Irwin, Inc., 1968). 
Matsuyama, Kiminori, 1992, "Agricultural Productivity, Comparative Advantage, and Economic Growth," Journal of Economic Theory, Vol. 58 (December), pp. 317-34.

Nkusu, Mwanza, 2004, "Aid and the Dutch Disease in Low-Income Countries: Informed Diagnoses for Prudent Prognoses," IMF Working Paper 04/49 (Washington: International Monetary Fund).

Nyoni, Timothy S., 1998, "Foreign Aid and Economic Performance in Tanzania," World Development, Vol. 26 (July), pp. 1235-40.

Prati, Alesandro, Ratna Sahay, and Thierry Tressel, 2003, "Is there a Case for Sterilizing Foreign Aid Inflows?" paper presented at the IMF Research Department workshop, "Macroeconomic Challenges in Low-Income Countries," October, Washington.

Salter, W. E. G., 1959, "Internal and External Balance: The Role of Price and Expenditure Effects," Economic Record, Vol. 35 (August), pp. 226-38.

Spatafora, Nikola and Andrew Warner, 1999, "Macroeconomic and Sectoral Effects of Terms-of-Trade Shocks: The Experience of the Oil-Exporting Developing Countries,” IMF Working Paper 99/134 (Washington: International Monetary Fund).

Stijns, Jean-Philippe, 2003, “An Empirical Test of the Dutch Disease Hypotheses Using a Gravity Model of Trade,” International Trade Working Paper No. 0305001 (St. Louis, Missouri: Washington University).

Torvik, Ragnar, 2001, “Learning By Doing and the Dutch Disease," European Economic Review, Vol. 45 (February), pp. 285-306.

Vos, Rob, 1998, “Aid Flows and 'Dutch Disease' in a General Equilibrium Framework for Pakistan,” Journal of Policy Modeling, Vol. 20 (February), pp. 77-109.

Yano, Makoto, and Jeffrey B. Nugent, 1999, “Aid, Nontraded Goods, and the Transfer Paradox in Small Countries,” American Economic Review, Vol. 89 (June), pp. 431-49.

Younger, Stephen D., 1992, “Aid and the Dutch Disease: Macroeconomic Management When Everybody Loves You," World Development, Vol. 20 (November), pp. 1587-97. 